\title{
Perbandingan Hasil Belajar Matematika Metode Snowball Throwing Disertai Pemberian Reward dan Tanpa Reward Pada Siswa
}

\author{
Evy Andriani ${ }^{1)}$, Nur Khalisah Latuconsina ${ }^{2)}$, Hasmiah Mustamin ${ }^{3)}$ \\ ${ }^{1,2,3}$ Fakultas Tarbiyah dan Keguruan UIN Alauddin Makassar \\ evyandriani25673@gmail.com ${ }^{1)}$, nur.khaalisah@uin-alauddin.co.id $^{2)}$, st.hasmiah.mustamin@uin- $^{2}$ \\ alauddin.ac.id $^{3)}$
}

\begin{abstract}
Abstrak
Penelitian ini bertujuan untuk mengetahui apakah terdapat perbedaan hasil belajar matematika antara yang menggunakan metode snowball throwing disertai pemberian reward dan tanpa reward pada siswa kelas VIII SMP Negeri 7 Bulukumba. Jenis penelitian ini adalah quasi experimental dengan desain non-equivalent control group design. Populasi dalam penelitian ini adalah siswa kelas VIII SMPN 7 Bulukumba yang terbagi dalam 3 kelas kemudian dilakukan penentuan sampel adalah sampling purposive. Teknik analisis yang digunakan adalah analisis statistik deskriptif dan analisis statistik inferensial. Berdasarkan hasil analisis deskriptif menunjukkan bahwa rata-rata hasil belajar siswa dengan menggunakan metode snowball throwing disertai pemberian reward adalah 81,79 dengan standar deviasi 13,856. Sedangkan metode snowball throwing tanpa pemberian reward adalah 72,67 dengan standar deviasi 14,132. Hasil analisis inferensial menunjukkan bahwa terdapat perbedaan hasil belajar antara yang menggunakan metode snowball throwing disertai pemberian reward dan tanpa reward dengan hasil perhitungan nilai $t_{\text {hitung }}>t_{\text {tabel }}(2,259>2,021)$ yang berarti $\mathrm{H}_{0}$ ditolak. Dengan demikian, dapat diketahui bahwa metode snowball throwing disertai pemberian reward dan tanpa reward dapat meningkatkan hasil belajar siswa kelas VIII SMP Negeri 7 Bulukumba.
\end{abstract}

Kata Kunci: Snowball Throwing, Reward, Hasil Belajar

\section{Pendahuluan}

Pendidikan merupakan suatu proses pengubahan sikap dan perilaku seseorang atau kelompok individu dalam upaya mendewasakan manusia melalui kegiatan pengajaran dan pelatihan. Sistem pendidikan nasional senantiasa harus dikembangkan sesuai dengan kebutuhan dan perkembangan yang terjadi baik di tingkat lokal, nasional maupun global. Oleh karena itu, pemerintah perlu berusaha keras untuk terus memperbaiki sistem pendidikan yang ada di Indonesia. Begitu penting pendidikan sehingga harus dijadikan prioritas dalam pembangunan bangsa, dan itu berarti diperlukan mutu pendidikan yang baik sehingga tercipta proses pendidikan yang cerdas, damai, terbuka, demokratif dan kompetitif. Untuk mewujudkan tujuan pendidikan tersebut dapat dicapai diantaranya melalui pembelajaran matematika.

Matematika merupakan ilmu yang mendasari perkembangan teknologi modern dan sebagai bahan atau alat yang akurat untuk menyelesaikan masalah-masalah ekonomi, sosial, fisika, kimia, biologi dan teknik. Peran inilah yang membuat matematika disebut sebagai Queen of science (ratunya ilmu). Melihat besarnya peranan matematika, maka pembelajaran matematika harus dibenahi dan mendapat perhatian yang serius. Pembelajaran matematika adalah proses memperoleh pengetahuan yang diciptakan atau dilakukan oleh siswa sendiri melalui pengalaman individu siswa (Risnawati, 2008). Berdasarkan survei Programme for International Student Assesment (PISA) pada tahun 2015, menyatakan bahwa prestasi matematika siswa Indonesia berada pada peringkat 63 dari 72 negara dengan skor rata-rata 386. Berdasarkan data survei tersebut dapat disimpulkan bahwa kondisi pembelajaran matematika belum memenuhi harapan. Salah satunya disebabkan karena sebagian besar 
model pembelajaran yang digunakan masih menggunakan model konvensional. Berdasarkan observasi, pembelajaran matematika di SMP Negeri 7 Bulukumba ditemukan beberapa kelemahan diantaranya adalah prestasi belajar yang masih kurang pada pembelajaran matematika. Hal ini ditunjukkan dengan hasil belajar matematika siswa masih banyak yang berada di bawah nilai KKM dimana nilai KKM yang ditetapkan oleh sekolah adalah 65 .

Permasalahan yang dijumpai dalam kelas adalah ditemukan pembelajaran yang berlangsung masih bersifat teacher centered. Guru menjelaskan konsep dan menyajikan rumus-rumus kepada siswa, kemudian siswa diminta untuk mengerjakan latihan. Belum tampak adanya proses menemukan sendiri dalam proses pembelajaran tersebut. Hal ini juga ditunjang dengan tidak adanya proses mencari, menemukan, dan mempelajari. Kemudian, para siswa juga jarang melakukan diskusi tentang pelajaran yang mereka pelajari dan jarang mengajukan pertanyaan walaupun guru sudah memberikan kesempatan untuk bertanya. Untuk lebih mengaktifkan pembelajaran di kelas agar hasil belajar dapat meningkat maka peneliti bermaksud menggunakan metode pembelajaran snowball throwing disertai pemberian reward dan tanpa reward. Metode pembelajaran snowball throwing disertai pemberian reward melibatkan siswa untuk menulis soal pada kertas, kemudian kertas tersebut dilipat atau dibuat bulatan kertas yang kemudian dilemparkan kepada siswa lain untuk dijawab dan siswa yang berhasil menjawab akan diberikan reward (hadiah) sehingga siswa tidak bosan dan bersemangat dalam kegiatan pembelajaran di kelas.

Metode pembelajaran snowball throwing tanpa pemberian reward juga melibatkan siswa dimana siswa menulis soal pada kertas, kemudian kertas tersebut dilipat atau dibuat bulatan kertas yang kemudian dilemparkan kepada siswa lain untuk dijawab hanya saja siswa yang berhasil menjawab tidak akan diberi reward. Berdasarkan penelitian yang dilakukan Efrita Ningsih (2012) yang menunjukkan bahwa penerapan metode snowball throwing dapat meningkatkan hasil belajar siswa. Selain itu terdapat juga penelitian yang dilakukan Mabarrun (2012) yang menunjukkan persentase keaktifan siswa pada siklus I sebesar 69\% dan meningkat pada siklus II menjadi $84,5 \%$. Sedangkan persentase banyaknya siswa yang mencapai nilai ketuntasan minimal sebesar $59 \%$ pada siklus I dan meningkat pada siklus II menjadi 79\%. Dengan demikian, dapat disimpulakan bahwa penerapan model pembelajaran snowball throwing disertai dengan pemberian reward dapat meningkatkan keaktifan belajar siswa kelas IX C MTs Miftahul Huda Mangunranan.

Berdasarkan uraian di atas, peneliti bermaksud untuk melakukan penelitian bagaimana perbedaan hasil belajar matematika menggunakan metode snowball throwing disertai pemberian reward dan tanpa reward. Penelitian ini bertujuan untuk memperoleh jawaban apakah terdapat perbedaan hasil belajar siswa yang mendapat pembelajaran menggunakan metode snowball throwing disertai pemberian reward dan tanpa reward. Oleh karena itu, kami mengambil judul penelitian tentang perbandingan hasil belajar matematika antara yang menggunakan metode snowball throwing disertai pemberian reward dan tanpa reward pada siswa kelas VIII SMP Negeri 7 Bulukumba.

Metode adalah cara yang digunakan untuk mengimplementasikan strategi. Hal yang perlu diperhatikan dalam metode adalah dalam menentukan metode pembelajaran, maka metode itu harus dapat mendorong siswa untuk beraktifitas sesuai dengan gaya belajarnya. Selain itu, pengalaman belajar juga harus mendorong agar siswa aktif belajar baik secara fisik maupun non-fisik. Jadi, proses pembelajaran sebaiknya dilaksanakan secara interaktif. Metode snowball throwing adalah cara belajar dengan melemparkan kertas yang berisi pertanyaan yang digulung bulat seperti bola ke siswa yang lain. Snowball throwing terdiri dari dua kata yaitu snowball dan throwing. Snowball berarti gumpalan salju atau berlemparan bola salju, sedangkan throwing berasal dari kata throw yang berarti lemparan atau melemparkan. Jadi snowball throwing berarti melemparkan bola salju (John M. Echolas dan 
Hassan Shadil, 2000). Adapun langkah-langkah dalam metode snowball throwing ini adalah: 1) guru menyampaikan materi yang akan disajikan, 2) guru membentuk kelompok-kelompok dan memanggil masing-masing ketua kelompok untuk memberikan penjelasan tentang materi, 3) masing-masing ketua kelompok kembali ke kelompoknya masing-masing, kemudian menjelaskan materi yang disampaikan oleh guru kepada temannya, 4) kemudian masing-masing siswa diberikan satu lembar kerja untuk menuliskan pertanyaan apa saja yang menyangkut materi yang sudah dijelaskan oleh ketua kelompok, 5) kemudian kertas tersebut dibuat seperti bola dan dilempar dari satu siswa ke siswa yang lain, 6) setelah siswa mendapat satu bola atau pertanyaan diberikan kesempatan kepada siswa untuk menjawab pertanyaan yang tertulis dalam kertas berbentuk bola tersebut secara bergantian, 7) guru memberikan kesimpulan, 8) evaluasi, 9) penutup.

Metode snowball throwing ini merupakan salah satu metode dari pembelajaran aktif yang mengarahkan atensi peserta didik terhadap materi yang dipelajarinya. Dalam metode ini, dibentuk kelompok yang diwakili ketua kelompok untuk mendapat tugas dari guru. Setelah itu, masing-masing siswa membuat pertanyaan pada satu kertas yang dibentuk seperti bola dan berisi pertanyaan atau soal lalu dilempar ke siswa lain yang masing-masing siswa menjawab pertanyaan dari bola yang diperoleh sehingga siswa bisa terlatih untuk bekerja secara kelompok. Metode ini bisa berjalan secara efektif dan efisien jika siswa bisa lebih aktif. Penerapan metode snowball throwing diharapkan siswa bisa mahir dalam mengerjakan soal-soal matematika yang lebih menantang dan siswa juga harus lebih aktif dalam proses pembelajaran matematika. Kegiatan melempar bola pertanyaan ini akan membuat kelompok menjadi dinamis dan menarik, karena kegiatan siswa tidak hanya berfikir kritis, menulis, bertanya, atau berbicara saja, tetapi mereka juga melakukan aktivitas fisik, yaitu menggulung kertas dan melemparkannya pada siswa lain. Dengan demikian, tiap siswa akan mempersiapkan diri karena pada gilirannya mereka harus menjawab pertanyaan dari temannya yang terdapat dalam bola kertas. Kondisi ini akan memberi dampak pada hasil belajar siswa. Dengan menggunakan metode ini, diharapkan agar materi pelajaran matematika dapat mudah dipahami dan meningkatkan hasil belajar siswa. Metode snowball throwing ini memiliki kelebihan-kelebihan yaitu: 1) melatih kesiapan siswa, dalam metode ini, siswa dituntut untuk bisa terampil menjelaskan kepada teman lainnya tentang materi yang diajarkan guru. Selain itu, mereka diperintahkan membuat soal dan teman lainnya menjawab soal yang mereka buat. Sehingga, setiap siswa terlatih untuk siap membuat soal dan siap mejawab bola pertanyaan yang dilemparkan teman mereka. 2) saling memberikan pengetahuan, saling memberikan pengetahuan akan tampak dari metode ini dengan sikap siswa yang terampil menjelaskan materi yang diajarkan guru kepada temannya sebagai ketua kelompok. Pengetahuan juga akan saling terisi dengan variasi soal yang dibuat oleh masing-masing siswa.

Kegiatan melempar bola pertanyaan ini akan membuat kelompok menjadi dinamis dan menarik, karena kegiatan siswa tidak hanya berfikir kritis, menulis, bertanya, atau berbicara saja, tetapi mereka juga melakukan aktivitas fisik, yaitu menggulung kertas dan melemparkannya pada siswa lain. Dengan demikian, tiap siswa akan mempersiapkan diri karena pada gilirannya mereka harus menjawab pertanyaan dari temannya yang terdapat dalam bola kertas. Kondisi ini akan memberi dampak pada hasil belajar siswa. Dengan menggunakan metode ini, diharapkan agar materi pelajaran matematika dapat mudah dipahami dan meningkatkan hasil belajar siswa.

Menurut Kamus Besar Bahasa Indonesia reward merupakan pemberian, hadiah (karena memenangkan suatu perlombaan, pemberian kenang-kenangan, penghargaan, penghormatan, tanda kenang-kenangan tentang perpisahan cendera mata. Hadiah adalah sesuatu yang diberikan kepada orang lain karena sudah bertingkah laku sesuai dengan yang dikehendaki yakni mengikuti peraturan sekolah dan tata tertib yang sudah ditentukan (Arikunto, 1990). Hadiah dapat juga dikatakan sebagai 
motivasi, tetapi tidaklah selalu demikian. Karena hadiah untuk suatu pekerjaan, mungkin tidak akan menarik bagi orang yang tidak senang dengan pekerjaan tersebut (Sadirman, 1990). Dari beberapa pengertian di atas, dapat diambil satu kesimpulan bahwa pemberian hadiah merupakan salah satu bentuk alat pendidikan dalam proses pembelajaran yang dilakukan guru untuk siswa sebagai suatu pendorong, penyemangat dan motivasi agar siswa lebih meningkatkan prestasi hasil belajar sesuai yang diharapkan. Dan diharapkan dari pemberian hadiah tersebut muncul kinginan dari si anak untuk lebih membangkitkan minat belajar yang tumbuh dari dalam diri siswa sendiri.

Hasil belajar adalah terjadinya perubahan pada diri siswa ditinjau dari tiga aspek, yaitu kognitif, afektif, dan psikomotorik siswa (Sudjana, 2004). Hasil belajar merupakan hasil dari suatu interaksi tindak belajar dan tindak mengajar (Dimyati dan Mudjiono, 2013). Artinya, hasil pembelajaran yang dikategorisasi oleh para pakar tidak dilihat secara fragmentaris atau terpisah melainkan komprehensif. Proses pembelajaran melibatkan dua subjek, yaitu guru dan siswa akan menghasilkan suatu perubahan pada diri siswa sebagai hasil dari kegiatan pembelajaran. Perubahan yang terjadi pada diri siswa sebagai akibat kegiatan pembelajaran bersifat non-fisik seperti perubahan sikap, pengetahuan maupun kecakapan. Perubahan yang terjadi pada diri siswa sebagai akibat kegiatan pembelajaran bersifat non-fisik seperti perubahan sikap, pengetahuan maupun kecakapan (Widoyoko, 2014).

\section{Metode Penelitian}

Penelitian ini merupakan penelitian dengan pendekatan kuantitatif. Metode penelitian kuantitatif dapat diartikan sebagai metode penelitian yang berlandaskan pada filsafat positivisme digunakan untuk meneliti pada populasi sampel tertentu, teknik pengambilan sampel pada umumnya dilakukan secara random, pengumpulan data menggunakan instrumen penelitian, análisis data bersifat kuantitatif atau statistik dengan tujuan untuk menguji hipótesis yang telah ditetapkan. Penelitian ini menggunakan penelitian eksperimen dengan jenis penelitian eksperimen semu (quasi eksperimental). Desain penelitian yang digunakan adalah non-equivalent control group design. Desain ini terdapat dua kelompok eksperimen yang diberi perlakuan (Sugiyono, 2015). Dua kelompok yang ada diberi pretest, kemudian diberikan perlakuan dan terakhir diberikan posttest. Pada kelas eksperimen 1 diberi perlakuan dengan metode snowball throwing disertai pemberian reward dan kelas eksperimen 2 diberi perlakuan dengan metode snowball throwing tanpa reward.

Penelitian ini dilaksanakan di SMP Negeri 7 Bulukumba Kabupaten Bulukumba provinsi Sulawesi selatan. Adapun populasi dalam penelitian ini adalah seluruh siswa kelas VIII SMP Negeri 7 Bulukumba tahun ajaran 2017-2018. Teknik sampling yang digunakan dalam penelitian ini adalah teknik purposive sampling. Sampel dalam penelitian ini adalah siswa kelas VIII A sebagai kelas eksperimen 1 dan siswa kelas VIII B sebagai kelas eksperimen 2. Pengumpulan data pada penelitian ini dilakukan dengan teknik tes tertulis dan observasi. Pada penelitian ini, dilakukan dua kali tes untuk setiap kelas, yaitu pretest dan posttest. Pretest dilaksanakan untuk mengetahui hasil belajar sebelum diberi perlakuan, sedangkan posttest dilaksanakan untuk mengetahui hasil belajar siswa setelah diberi perlakuan. Bedasarkan hasil pretest dan posttest, dapat diketahui hasil belajar siswa terjadi peningkatan atau tidak terjadi peningkatan. Instrumen yang digunakan pada penelitian ini berupa soal essay. Pengolahan data hasil penelitian digunakan dua teknik statistik, yaitu statistik deskriptif dan statistik inferensial. Analisis statistik deskriptif digunakan untuk mengetahui gambaran secara umum hasil belajar siswa. Analisis statistik inferensial digunakan untuk menguji hipótesis penelitian dengan menggunakan uji independent sample t-test. Namun, sebelumnya dilakukan terlebih dahulu uji normalitas dan uji homogenitas sebagai uji prasyarat. 


\section{Hasil}

Berdasarkan data hasil belajar matematika siswa pada kelas eksperimen 1 dengan menggunakan metode snowball throwing disertai pemberian reward sebelum dan setelah diberi perlakuan di kelas VIII A pada mata pelajaran matematika. Berikut ini adalah tabel analisis deskriptif data hasil belajar matematika yang menggunakan metode snowball throwing disertai pemberian reward.

Tabel 1. Deskripsi Pretest dan Posttest Kelas Eksperimen 1

\begin{tabular}{lccccc}
\hline \multicolumn{7}{c}{ Descriptive Statistics } \\
\hline & $\boldsymbol{N}$ & Minimum & Maximum & Mean & Std. Deviation \\
\hline Pretes Eksperimen1 & 24 & 2 & 65 & 28.58 & 17.078 \\
Posttes Eksperimen1 & 24 & 55 & 100 & 81.79 & 13.856 \\
\hline
\end{tabular}

Berdasarkan tabel di atas dapat diketahui bahwa nilai minimum dan maksimum pretest kelas eksperimen1 berturut-turut adalah 2 dan 65 dengan standar deviasi sebesar 17,078 artinya sebagian besar data pada kumpulan berjarak plus atau minus 17,078 dari rata-rata. Selain itu, dari tabel 1 dapat pula diketahui nilai minimum dan maksimum hasil belajar matematika kelas eksperimen1 setelah diberi perlakuan berturut-turut adalah 55 dan 100 dengan standar deviasi sebesar 13,856 artinya sebagian besar data pada kumpulan berjarak plus atau minus 13,856 dari rata-rata.

Tabel 2. Kategori Hasil Belajar Matematika Kelas Eksperimen 1 Sebelum dan Setelah diberikan Perlakuan

\begin{tabular}{clcccc}
\hline \multirow{2}{*}{$\begin{array}{c}\text { Tingkat } \\
\text { Penguasaan }\end{array}$} & \multirow{2}{*}{ Kategori } & \multicolumn{2}{c}{ Pretest } & \multicolumn{2}{c}{ Posttest } \\
\cline { 3 - 6 } & & Frekuensi & Persentase (\%) & Frekuensi & Persentase (\%) \\
\hline $0-19$ & Sangat Rendah & 7 & 29,17 & 0 & 0 \\
$20-39$ & Rendah & 11 & 45,83 & 0 & 0 \\
$40-59$ & Sedang & 5 & 20,83 & 2 & 8,33 \\
$60-79$ & Tinggi & 1 & 4,17 & 7 & 29,17 \\
$80-100$ & Sangat Tinggi & 0 & 0 & 15 & 62.5 \\
\hline \multicolumn{2}{c}{ Jumlah } & 24 & 100 & 24 & 100 \\
\hline
\end{tabular}

Pada tabel di atas dapat dilihat bahwa sebelum diberikan perlakuan (pretest) terdapat 7 siswa $(29,17 \%)$ berada pada kategori sangat rendah, 11 siswa $(45,83 \%)$ berada pada kategori rendah, 5 siswa $(20,83 \%)$ berada pada kategori sedang, 1 siswa $(4,17 \%)$ berada pada kategori tinggi dan tidak ada siswa pada sangat tinggi. Sedangkan setelah diberikan perlakuan (Posttest) tidak terdapat siswa (0\%) pada kategori sangat rendah dan rendah, 2 siswa $(8,33 \%)$ berada pada kategori sedang, 7 siswa $(29,17)$ berada pada kategori tinggi dan 15 siswa $(62,5 \%)$ berada pada kategori sangat tinggi. Sehingga dapat disimpulkan bahwa persentase terbesar kelas eksperimen1 sebelum diberi perlakuan berada pada kategori rendah sedangkan setelah diberikan perlakuan kelas eksperimen1 berada pada kategori sangat tinggi. 
Tabel 3. Deskripsi Pretest dan Posttest Kelas Eksperimen 2

\section{Descriptive Statistics}

\begin{tabular}{lccccc}
\hline & N & Minimum & Maximum & Mean & Std. Deviation \\
\hline Pretest Eksperimen 2 & 24 & 2 & 54 & 28.08 & 18.120 \\
Posttest Eksperimen 2 & 24 & 50 & 90 & 72.67 & 14.132 \\
\hline
\end{tabular}

Berdasarkan tabel 3, dapat diketahui nilai minimum dan maksimum kelas eksperimen 2 sebelum dan setelah diberikan perlakuan. Pada tabel tersebut nilai minimum dan maksimum pretest kelas eksperimen 2 berturut-turut adalah 2 dan 54 dengan rata-rata 28,08 dan standar deviasi sebesar 18,120 artinya sebagian besar data pada kumpulan berjarak plus atau minus 18,120 dari rata-rata. Selain itu, dari tabel 3 dapat pula diketahui nilai minimum dan maksimum hasil belajar matematika kelas eksperimen 2 setelah diberi perlakuan berturut-turut adalah 50 dan 90 dengan rata-rata 72,67 dan standar deviasi sebesar 14,132 artinya sebagian besar data pada kumpulan berjarak plus atau minus 14,132 dari rata-rata.

Tabel 3. Kategori Hasil Belajar Matematika Kelas Eksperimen 2

\begin{tabular}{clcccc}
\hline \multirow{2}{*}{$\begin{array}{c}\text { Tingkat } \\
\text { Penguasaan }\end{array}$} & \multirow{2}{*}{ Kategori } & \multicolumn{2}{c}{ Pretest } & \multicolumn{2}{c}{ Posttest } \\
\cline { 3 - 6 } & & Frekuensi & Persentase (\%) & Frekuensi & Persentase (\%) \\
\hline $0-19$ & Sangat Rendah & 9 & 37,5 & 0 & 0 \\
$20-39$ & Rendah & 9 & 37,5 & 0 & 0 \\
$40-59$ & Sedang & 6 & 25 & 6 & 25 \\
$60-79$ & Tinggi & 0 & 0 & 9 & 37,5 \\
$80-100$ & Sangat Tinggi & 0 & 0 & 9 & 37,5 \\
& Jumlah & 24 & 100 & 24 & 100 \\
\hline
\end{tabular}

Pada tabel 3 di atas dapat dilihat bahwa sebelum diberikan perlakuan (pretest) terdapat 9 siswa $(37,5 \%)$ berada pada kategori sangat rendah, 9 siswa (37,5\%) berada pada kategori rendah, 6 siswa $(25 \%)$ berada pada kategori sedang, dan tidak ada siswa berada pada kategori tinggi dan sangat tinggi. Sedangkan setelah diberikan perlakuan (posttest) tidak terdapat siswa (0\%) pada kategori sangat rendah dan rendah, 6 siswa (25\%) berada pada kategori sedang, 9 siswa (37,5\%) berada pada kategori tinggi dan 9 siswa $(37,5 \%)$ berada pada kategori sangat tinggi.

Tabel 4. Hasil Uji Independent T-Test Hasil Belajar Matematika Kedua Kelas

\begin{tabular}{cccccccc}
\hline \multicolumn{7}{c}{ Independent Samples Test } \\
\hline & $\boldsymbol{F}$ & Sig. & $\boldsymbol{t}$ & $\boldsymbol{d} f$ & $\begin{array}{c}\text { Sig. (2- } \\
\text { tailed) }\end{array}$ & $\begin{array}{c}\text { Mean } \\
\text { Difference }\end{array}$ & $\begin{array}{c}\text { Std. Error } \\
\text { Diference }\end{array}$ \\
\hline Posttest & 0.243 & 0.624 & 2.259 & 46 & 0.029 & 9.125 & 4.040 \\
& & & 2.259 & 45.982 & 0.029 & 9.125 & 4.040 \\
\hline
\end{tabular}


Berdasarkan tabel di atas terlihat jelas bahwa hasil belajar siswa pada pretest dan posttest mengalami peningkatan dimana nilai posttest jauh lebih baik dibandingkan pretest, dan hasil belajar siswa pada kelas eksperimen 1 lebih tinggi daripada kelas eksperimen 2.

\section{Pembahasan}

Berdasarkan hasil análisis dapat disimpulkan bahwa $H_{0}$ ditolak, ini berarti bahwa terdapat perbedaan rata-rata hasil belajar matematika antara kelas yang menggunakan metode pembelajaran snowball throwing disertai pemberian reward dan kelas yang menggunakan metode pembelajaran snowball throwing tanpa reward pada siswa kelas VIII SMP Negeri 7 Bulukumba. Berdasarkan pengamatan dan hasil análisis peneliti diperoleh bahwa terdapat perbedaan rata-rata pada penerapan metode snowball throwing disertai pemberian reward dan tanpa reward terhadap hasil belajar, hal ini dikarenakan baik kelas eksperimen 1 dan eksperimen 2 sama-sama diberi perlakuan metode snowball throwing sehingga mampu meningkatkan hasil belajar siswa, hanya saja yang membedakan adalah pemberian reward, kelas yang diberi reward nilai rata-ratanya lebih tinggi karena dengan diberikan reward siswa jadi semangat untuk belajar. Meskipun terdapat perbedaan, tetapi dalam pembelajaran matematika keduanya sama-sama mampu meningkatkan hasil belajar siswa. Dengan menggunakan metode snowball throwing disertai pemberian reward mampu membuat hasil belajar matematika siswa meningkat. Hal ini dikarenakan siswa lebih aktif dan bersemangat dalam belajar karena diberi reward, sedangkan penerapan metode snowball throwing tanpa pemberian reward juga mampu meningkatkan hasil belajar meskipun tidak sama meningkatnya dengan metode snowball throwing disertai pemberian reward.

\section{Kesimpulan}

Berdasarkan hasil analisis deskriptif dan inferensial dapat disimpulkan bahwa: 1) Hasil belajar matematika siswa yang diberi perlakuan dengan pembelajaran metode snowball throwing disertai pemberian reward yaitu diperoleh hasil belajar matematika siswa berada pada kategori sangat tinggi dengan persentase $62,5 \%$. 2) Hasil belajar matematika siswa yang diberi perlakuan dengan pembelajaran metode snowball throwing tanpa pemberian reward yaitu diperoleh hasil belajar matematika siswa berada pada kategori sangat tinggi dengan persentase 37,5\%. 3) Terdapat perbedaan rata-rata hasil belajar matematika antara siswa kelas eksperimen 1 dan kelas eksperimen 2.

\section{Daftar Pustaka}

Arikunto, Suharsimi. 2006. Dasar-Dasar Evaluasi Pendidikan. Jakarta: Bumi Aksara.

Dimiyati dan Mudijono. 2002. Belajar dan Pembelajaran. Jakarta: Rineka Cipta.

Echolas, M. John dan Hassan Saddily. 2000. Kamus Inggris-Indonesia. Jakarta: Gramedia Jakarta Pustaka Utama.

Mumun Monawaroh. 2017. Pengaruh Penerapan Model Pembelajaran Snowball Throwing Terhadap Hasil Belajar Matematika Siswa dengan Pokok Bahasan Relasi dan Fungsi, Jurnal Pendidikan Matematika IAIN Sykh Nurjati Cirbon, Vol.3 No.2.

Risnawati. 2008. Strategi Pembelajaran Matematika. Pekanbaru: Suska press.

Sardiman, AM. 1990. Inetraksi dan Motivasi Belajar Mengajar. Jakarta: Rajawali Pers.

Sudjana, Nana. 2004. Dasar-Dasar Proses Belajar Mengajar, Bandung: Sinar Baru Algesindo.

Suprijono, Agus. 2010. Cooperative Learning. Yogyakarta: Pustaka Pelajar.

Sugiyono. 2015. Metode Penelitian Kombinasi. Bandung: Alfabeta.

Sugiyono. 2008. Statistika untuk Penelitian. Bandung: Alfabeta.

Widoyoko, Eko Putra. 2014. Evaluasi Program Pembelajaran (Panduan Praktis Bagi Pendidikan dan Calon Pendidik Cet. VI). Yogyakarta: Pustaka Belajar. 